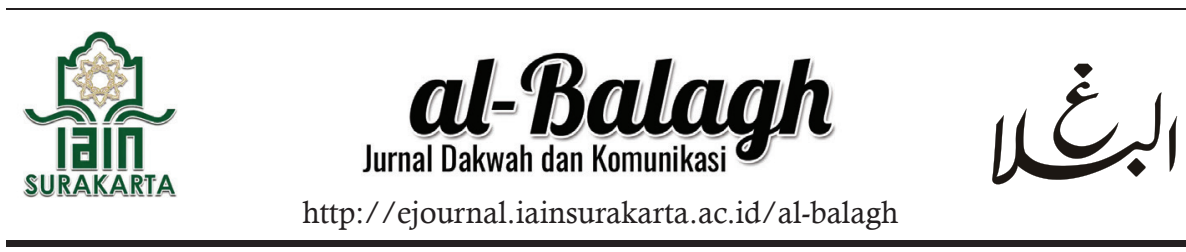

\title{
DEVELOPING INTERNAL MEDIA REGULATION FOR LOCAL MEDIA BASED ON COMMUNITY
}

\author{
Sunarto \\ Adi Nugroho \\ Amida Yusriana \\ Universitas Diponegoro Semarang
}

\begin{tabular}{l}
\hline Keywords: \\
local \\
community; \\
internal regulation \\
of media; local \\
media
\end{tabular}

media

\begin{abstract}
A serving community is a strategic plan that needs to be considered by several local newspaper production in Java. This includes a newspaper in Semarang, Suara Merdeka Daily. This study determines the commitment of Suara Merdeka Daily in serving the community. Data were obtained from the analysis of internal regulatory content on editorial work and business. This study used Focus Group Discussions (FGD) to support and share data with the newspaper management team. The results showed that the editorial's internal regulations did not explicitly indicate the commitment to serve the community. This regulation has been implemented for a long time, yet it does not adjust to the relevant newspapers' actual conditions. Generally, businesses have rules that require community involvement in their programs. The management team is expected to revise the regulations to suit the public's needs and develop relevant community involvement for the local newspaper's existence.
\end{abstract}

Correspondence:

e-mail: sunartoo@yahoo.com adinugroho.semarang@gmail.com amidayusriana88@gmail.com 


\begin{tabular}{l}
\hline \\
\hline Kata kunci: \\
masyarakat; \\
media lokal; \\
regulasi internal \\
media
\end{tabular}

\section{How to cite (APA 7th Edition):}

Sunarto, Nugroho, A., \& Yusriana, A. (2020). Developing Internal Media Regulation For Local Media Based On Community. Al-Balagh: Jurnal Dakwah Dan Komunikasi, 5(1), 141-164. https://doi.org/10.22515/albalagh.v5i1.2169

\section{INTRODUCTION}

Mass media are an essential means of delivering information to the public. The information conveyed is realized through forms or news products. Maulsby (1925) stated that news is an actual narrative that is impartial to the facts conveyed and has essential, and actual meaning to attract the attention of the reader. Therefore, the mass media's local and national news needs to be relevant and balanced. The message conveyed is often intended for the wider public, hence the need for relevance. 
In Indonesia, most local media are in the critical economic situation, which is likened to the sunset industry. As business entities, they face the rapid development of communication technology that forces them to change their future survival (Sunarto et al., 2016).

The number of media development in Indonesia has decreased gradually. For instance, there were 418 daily newspapers in 2014. The number significantly reduced to 398 in 2018. Additionally, the decrease is evident in weekly newspapers, such as magazines and tabloids. The report showed that the number of daily newspapers also decreased significantly. For instance, there were 9.649 .784 daily newspapers in 2014. However, they decreased to 6.348.791 exemplars in 2018, showing discontinuation of at least 3.300.993 (Serikat Perusahaan Pers, 2018).

Many newspapers closed their businesses due to economic instability in facing new media. This condition is evident in the national and global context. From the website https://www.remotivi.or.id/, the Alliance of Independent Journalists (AJI), in its year-end notes, refers to Nielsen's data from 117 letters. According to the news, 16 media units were declared bankrupt in 2015. Also, there is a decline in active magazines from 170 to 132. In this case, this data's development may be continued based on how the media maintains its existence, following technological developments. The media institutions that cannot keep pace with technological advancements are forced out of business. For instance, Sinar Harapan closed on January 2016, Harian Bola ended its publication on October 2015, the Jakarta Globe was terminated on December 2015, and Sunday Tempo Newspaper closed on October 2015 (Utomo, 2015). Furthermore, Utusan Malaysia in Malaysia (Iqbal, 2019); Tribune, The New York Times, Reader's Digest, Newsweek, Rocky Mountain News in the USA (Tempo. co, 2013); Bernas Daily, Joglosemar, and several magazines, including Kawanku, Sinyal, Chip, What Hi-Fi, Auto Expert, Car and Turning Guide, and Motor, specifically transformed into cewekbanget.id and grid.co.id (Rizky, 2018). 
According to Nielsen Indonesia's research, print media readers were 9.5 million 5 years ago. However, the number dropped dramatically to 4.5 million. At the same time, media readers or digital platforms are 6 million. In this context, generation $\mathrm{X}$ and the millennial generation are considered the largest digital media readers (Mulia, 2020). Moreover, based on data from internet users through the Internet Service Providers Association (Asosiasi Penyelenggara Jasa Internet/APJII) website, it was stated that throughout 2017, out of total Indonesia's population of 262 million people, more than $50 \%$ or 143 million had been connected to the internet (Rizky, 2018). However, the consumption of print and digital media is still considered to vary with each generation. Newspapers are considered to still have a bargaining value by displaying the depth of news content that cannot be possessed by other digital media (Mulia, 2020).

Several studies showed pessimism and optimism about the future of local media. In the US, it was reported that thousands of local papers had recently closed. Millions of people did not have significant sources of local news on community activities. They could not know what is happening in their local communities. Therefore, people could not foster civic engagement that is important to support government objectives. The rest of the papers must decrease their reporters, coverage, and circulation (Hendrickson, 2019). This impacted several media in Indonesia, like Sindo Yogyakarta, which dismissed its 42 employees in 2016 (Rizky, 2018).

There are few studies on local media focusing on the internal organizational aspect. Several studies only focus on the content and ideal roles of local media in their communities (Firmstone, 2016; Hess, 2012; Hess \& Waller, 2013), it is a financial crisis because its local readers left it (Wadbring \& Bergström, 2015; Shaker, 2014), the changing role of local media in the public communication (Firmstone \& Coleman, 2014), and assessing local media by its communities (Napoli et al., 2016). 
The studies did not focus on how organizational media internally operate in the digital era. A study about organizational media focused on the leadership issue, which is not related to internal regulation (Sunarto, Nugroho, et al., 2018). Furthermore, there are few studies on local media based on internal policy or management. Studies on media management did not address organizational media internal policy (Strube, 2010; Sylvie \& Weiss, 2012)

In a study on the impact of formal standards and regulation on companies' innovation efficiency, Blind et al., (2017) showed the importance of internal regulation based on the community. The study showed that formal standards and regulations have different effects, depending on the extent of market uncertainty. Furthermore, formal standards lead to lower innovation efficiency in markets with low uncertainty. In contrast, regulations lead to increased innovation, efficiency, and uncertainty.

According to Koop \& Lodge (2017), the study about regulation involves a control system that requires the existence and functioning of 3 components. These components include standard-setting (the statement of the desired state of the world), information-gathering (the tools used to distinguish the actual from the desired state of the world), and behavior-modification (the tools used to align actual with desired states of the world).

Based on the study, it is assumed that internal media policy, as a regulation of local media that developed based on its community interests, was essential to support and guide organizational, local media to achieve its goals. It would be a center of editorial or commercial local media activities to realize their objectives as strategic planning. Furthermore, it would give a consequence to serve the community as a primary source for all activities. It would unite interests of editorial and commercial activities to be an organizational objective to solve its economic problems. 
The internal regulation defines the procedures to be followed for the administrative operation and organization of the institution. Moreover, the regulation outlines the implementation of rules, and the imposition of sanctions for violation or nonconformity to relevant laws (Aristotle University of Thessaloniki, 2020; Romero \& Lambropoulos, 2011). Internal media regulations comprise documents with the objectives to be achieved by a local paper in editorial and business matters in everyday activities. It was part of actualizing internal media policy to develop strategic planning in general. Furthermore, it could guide employees to work well and achieve their organizational goals. Apart from that, the local community consists of people living in the local region, which are grouped based on their professions, hobbies, locations, among other classifications.

Based on the description above, this study was conducted at the organizational communication level. It examined the local media as a commercial organization, where its central business was not only to spread information and entertainment to society but also to benefit financially from its consumers. There are 3 approaches that were used to explain the phenomena, including classical, human relations, and contemporary approaches (Albarran, 2006). The classical approach was the most relevant in understanding the internal regulation of local media. It focuses on how to make organizations more productive. Therefore, management is responsible for establishing defined job responsibilities, maintaining close supervision, monitoring output, and making important decisions.

Taylor, the founder of the scientific management approach, stated that this approach offered a systematic way toward the challenge of increasing production. This could be achieved by effectively coordinating tasks, selecting and economically motivating employees, as well as training and adequately developing the workplace. Research on media management developed an object of interest and study during the twentieth century. It happened when the media conglomeration started to participate in 146 
newspaper, radio, film, and television industries. This phenomenon began to be studied since media has a significant role as a source of information and entertainment, as well as cultural transmission channels in the community. The research development continued not only on the ownership issue but also in media convergence, market share, cash flow, developing a new product, and expanding business models. Moreover, the research covered the implementation of new technologies, as well as responding to competition and external factors (Albarran, 2006).

A discussion on internal media regulation cannot be separated from the issue of media governance. These issues deal with laws, rules, regulations, and conventions. It serves common interests, including those of media industries. Additionally, it concerns formal and obligatory rules, as well as the informal mechanism of both internal and external media. Consequently, the rules may guide the multiple and inconsistent media objectives (McQuail, 2005).

Media governance has several purposes, such as protecting substantial concerns of the state and public order, as well as inhibition of public harm. Additionally, it defends individual rights and interests. Media governance meets the needs of the media industry to operate optimally, promotes freedom, communication, and cultural values, as well as encouraging technological innovation and economic enterprise. Furthermore, it sets technical and infrastructural standards, meets international obligations, and encourages media accountability. These are among the purposes of media governance, which need to be learned when discussing media policy (McQuail, 2005).

The main form of media governance is apparent in two dimensions, including performances (formal, informal), and scopes (internal, external) (McQuail, 2005). The formal performance of media governance in external scope is actualized in the laws and regulations applicable to public regulatory bodies. The internal scope represents the administration, 
self-regulation, and organizational culture. The informal performance of media governance in external scope is reflected as market forces, lobby groups, public opinion, review, and criticism. The internal scope includes professionalism, ethics codes, and conduct. Additionally, one form of media governance in formal performance and external scope is emphasized in management processes and self-regulation.

One of the media governance aspects is related to management processes and self-regulation. This aspect is essential for a media institution to achieve its goals. Management is the effective and efficient achievement of media organizational goals through planning, organizing, leading, and controlling resources (Daft, 2012). Planning is identifying many goals for future organizational performances, and the determination of tasks and resources used to achieve the goals. Organizing concerns with determining and classifying tasks and allocating organizational resources. Leading represents the use of influence to motivate employees to achieve organizational goals. Controlling is monitoring employees' activities, determining the consistency of the organization's path with its objectives, and making necessary corrections.

All management activities are directed to create better self-regulation. An organization supports its effort in achieving its goals when it has rules. Documenting all processes helps the organization in conducting itself to realize its purposes. With the self-regulation standard, all employees behave according to organizational ethics in order to achieve the goals. This provides the most effective way to coordinate the employees' tasks. As part of a strategic way to achieve their objectives, media organizations must document the standard guidelines for all employees to function effectively.

A document should consist of anything that is considered strategic by the organization. It means extensive planning with a long term orientation to interact with its environment to achieve organizational 148 
goals. The strategic dimensions relate to the decision of top management, enormous resources, future orientation, multifunction and multi-users consequences, and external conditions (Pearce II \& Robinson, Jr., 2016).

To determine a strategic document, the management must define organization vision to include intentions, philosophies, and goals. Additionally, the document analyzes internal conditions and organization competency, as well as evaluates external conditions, including competitors and general contextual factors. Furthermore, the management has to analyze the choices related to resource availability, external environment, and identify the most desirable options and evaluate them based on the organization's mission. It is essential for management to determine longterm goals and the main strategies of achieving them. Equally important is creating years' objectives and short-term strategy relevant to long-term goals and the main strategy. Nevertheless, Pearce II \& Robinson, Jr. (2016) reminded the management to implement strategic choices relevant to budget and resource allocation. Finally, the management has to evaluate the result of the strategic processes as future input.

The strategic document provides many benefits, such as empowering organizational competencies to defend problems, the best decision-making based on a group of employees as the best alternative, and decreased resistance to organizational changes. The document has to describe how strategic consumers become the organization-targets, such as the community. This study defines community as a unified body of people with common interests living in a particular area. It is also a group of people with a common characteristic or interest, living together within a larger society (Merriam-Webster, 2018).

Based on communication, the community had meaning related to a ritual view of communication. It means that communication is designed to maintain society and represent shared beliefs (Radford, 2005). When people come together in a community, they share the same identity related 
to their experiences, activities, hobbies, professions, or something else. They have the same beliefs about their interests. Also, they find the fulfillment of their identities within the community. It is seen when the members of a community meet one another in certain regular events. They enjoy their meeting by collecting photos and publishing them in the newspaper.

Based on the descriptions above, the problem of this study is formulated as follows. Did the local paper create its internal regulations as part of strategic planning and explicitly declare its concern to its community to cope with organizational objectives? Did editorial and commercial matters in the regulation consist of the community interests? Therefore, this study describes a community's existence in the internal regulation of the local paper concerning editorial and commercial matters. It was essential to know and ensure that all the innovations by local newspaper leaders would be explicitly established at the strategic planning level. The information was obtained from SM daily as a research site because it was one local newspaper in Central Java that was gradually losing its readers.

\section{METHODS}

This is qualitative descriptive research. The data were sourced from text and field research. Data were collected using content analysis of internal regulation and Focus Group Discussion (FGD) of the management teams of SM daily. The FGD was used to support the content analysis. Furthermore, the secondary data were obtained from several book references, journals, or other indirect sources relevant to the research topic.

Suara Merdeka (SM) daily was chosen as the object of research because it was an iconic local paper in Central Java with a large publication in this region. The distribution scope of SM Daily consists of several regions, including Semarang Metro (Semarang, Kendal, Demak, Salatiga, 
Purwodadi, Grobogan), Suara Pantura (Tegal, Pekalongan, Brebes, Pemalang, Batang), Suara Muria (Jepara, Kudus, Blora, Pati, Rembang), Suara Suara Banyumas (Purwokerto, Banjarnegara, Cilacap, Purbalingga), Suara Kedu/DIY (Purworejo, Kebumen, Wonosobo, Yogyakarta, Temanggung, Magelang), and Solo Metro (Surakarta, Sragen, Sukoharjo, Boyolali, Karanganyar, Klaten) (Merdeka, 2019).

Content analysis was conducted to obtain information from editorial and business matters in 2019. The editorial regulation was stated in Buku Pintar Wartawan (Sadono \& Thobary, n.d.) and Lebib Padat Lebih Segar Lebih Cerdas (Sudarto et al., 2011). The business regulation was stated in Marcomm Strategy 2019, as well as Marketing Event and Promotion Plan 2019. There was an examination to find the explicit existence of the community in both regulations. The Focus Group Discussion (FGD) was conducted with Editor in Chief, Consultant Management, Marketing Communication Manager, and Circulation Manager of SM Daily.

\section{RESULTS AND DISCUSSION Internal Regulations and Compliance}

The result showed that the editorial regulation consists of 13 chapters related to the general description of local paper groups, guidelines of daily work, writing standard that is fit for printing, editorial policy, and analysis of the department's position. Furthermore, the regulation covered the determination of working hours, guidance of religion writing, headlines, cooperation, legislative councils, the language in news writing, agriculture, labor, and legal writing.

There were no explicitly written communities in the regulation. According to pages 27-28 of the regulation, all editorial policies should consider business aspects without failing to defend the subordinate group of people in society. This paper served everyone in Central Java and others that had a primordial connection with this region. The paper stated 
that it had to align with the relationship between editorial policy and the company's stakeholders, such as government, security officers, customers, advertisers, owners, banks, and others.

Aware of its history, this paper had positioned itself as a Central Java publication. It lives and grows together with the dynamics of people in Central Java. This paper lives in the middle of Central Java culture, with a marketing base in this region. Therefore, the strong point of news and editorial policy prioritized all matters and interests of the province.

The Lebih Padat Lebih Segar Lebih Cerdas contained 3 topics, including standard of pages performance, the guidance of writing, and tips, and therapy. The first topic exposed several criteria related to numbering in titles, raw numbers in title and sub-titles, maximizing columns, captions, features, interactive editorial rubric, infographics, author names, source, and author photography, as well as advertorials. The second topic explained more about the title (essence, efficiency, effectiveness, highlight), headlines, text content, captions, features, and infographics. The last one described the guidelines for reporters, editors, and lay outer.

Both of the internal editorial regulations did not mention anything related to the community explicitly. According to Editor in Chief of this paper, the community is mentioned explicitly as a tagline Adhesive of Central Java Community, which covers an extensive meaning. It includes social groups that develop Central Java sociologically.

Responding to these findings, the Editor in Chief stated that the internal regulations contained in the SM did not mention that aspect. This is because the definition in question applies to people outside Semarang and Central Java, as long as it is still within the people of Central Java. In this case, the Editor in Chief acknowledged that internal regulation in editorial matters was treated as a guideline to control their products. As a performance standard, it was used to serve news and information to the public. This is consistent with the additional statement from the Editor in Chief of SM Daily. 
"As industrial products produced by journalists in their positions as reporters and editors, they must use the guidelines as performance standards to present news and information to the public. The handbook is essential as a basis of product standardization for the newspaper products to be curated by the audience."

Related to the development of internal media regulations, the Consultant of Management explained that SM had not conducted detailed internal regulations on the media for long. In its context, media life is empirically carried out with guidance, and all departments are given instructions according to what is necessary. According to this opinion, new formal internal regulations are absent, especially in editorial matters, which consists of details about the community.

"When needed, the guidance on how business print media must be conducted in this paper is written. Now, it is only practiced empirically with clear guidance."

Thehe media should be managed by preparing an organizational plan. It is essential to formulate formal organizational goals and plans. It is used as a source of legitimacy, motivation and commitment, resource allocation, guidelines for action, the basis for decision making, and measuring standard performance (Daft, 2012).

Organizational goals are achieved effectively when everything related to this success is written in a formal internal regulation. It creates a shared understanding of all members of the organization about how to achieve their goals. Hence, Sadiq \& Governatori (2015) explained that regulation is used to obtain all organizational members' compliance. Compliance is essential because, without it, all organizational goals cannot be achieved successfully. It ensures that business processes, operations, and practices align with a prescribed and agreed-upon set of norms. The needs of compliance decrease from the legislature and regulatory bodies, 
standards, codes of practice, and business partner contracts. The biggest challenge is to combine the control objectives that cannot reduce rules and regulations with the business objectives and performances.

Serving the community as a new strategy may not be actualized by all the editorial department employees in the absence of explicit guidelines. As a basis of action, the new commitment to serve the local community should be mentioned explicitly in all documents related to editorial issues. Mentioning about society or marketing targets is a general term that describes their new area of service. It gives nothing to all employees to serve more to their actual communities. In contrast to this condition, Pearce II \& Robinson, Jr. (2016) stated that the documents containing strategic ways would empower organizational competencies to defend problems and reduce rejection of changes.

\section{Ideal Process of Developing Regulation Based on Community Interest}

There is no ideal situation in processing information from top management to the bottom line. There was a different meaning of community in management. According to the Editor in Chief, the local paper defined community-based sub-culture in Java geographically, such as Kedu, Magelang which differ from the sub-culture of Muria, Pantura, Semarang, and other surroundings. Related to this matter, the Editor in Chief explained,

"They exist to serve the sub-culture communities by actualizing their services through rubrics that provide direct involvement, such as giving Banyumasan dialect, or written east dialect. They also use symbols to represent certain subcultures, such as sopo iki (who is this) for Semarang or sopo leh $i k i$ (who is this) for Muria. They try to enter directly into the nuance of their traditional readers." 
This local newspaper lacks the same meaning and fails to mention explicitly the community as the main target in the internal regulation. Therefore, it fails to recall what World Association Newspaper (WAN) said when reminding all the newspaper management not to exclude their reader community. This reminder was essential to be emphasized by all local newspaper leaders for them to survive in the new technology (Sularto, 2012).

A local newspaper, SM Daily is no exception, because it should manage the system independently and openly. To be more productive, the organization's system implemented in the media must be open to its environment. In line with this interpretation, the media's organizational context must have five components, including input, change process, output, feedback, and environment (Daft, 2012).

The input component is related to information, financial and human resources. The organization processes could change all the resources as an output, whether services or products. After producing the output, the organization would receive feedback from its internal or external stakeholders. All the components would be processed in a certain environment.

In this study, the local paper received input as information from its top leader and environment. There are new changes in the environment, such as new communication technology development. As a result, it inspires local paper's leaders to identify anything that might be used as an essential input. In this case, the local community and adaptation to current conditions are the input. The local leader needed to change their organizational orientation to suit the new condition. They viewed the existence of community as an essential factor that was useful as a survival tool for their paper. Therefore, the leader decided to emphasize the local community as a basic strategic orientation to survive in the future. 
McQuail (2005) stated that a newspaper lacks good governance when its internal mechanism cannot define the meaning of the same community to be included in the paper's main target. The processes in editorial matters fail to fulfill the task of determining the community as desired by the top management.

For this reason, the strategic steps determined basically should be well communicated to all employees in each department. However, based on this research, there was a problem in the communication process, especially in the editorial department, because there was no local community in their internal regulation. There were different meanings of community among the editorial staff. Environment input could not be appropriately processed at the editorial management level due to the absence of community tracking in its regulation. As a policy, an idea to serve the local community was not well communicated in the editorial department. The editorial department translated the idea about different communities from the top leader. When the community's publication appeared, it seemed to be dwelling more on the advertising interest, such as the automotive community. However, there was no other community (Sunarto, Purbaningrum, et al., 2018).

\section{Business to Community}

Internal regulation on business matters might be found in Marcomm Strategy 2019, as well as Marketing Event and Promotion Plan 2019. In the first business regulation, only one out of the 13 strategies addressed community actualization. In the second business regulation, 11 out of 33 programs targeted communities especially. Based on the data, some ideas were applied by the local newspaper to engage with its community, including newspaper bundling to the community, QR Code, co-working space, and news serials of community. 
Bundling is a practice of entering 2 or 3 products in separate products. It is the most flexible product strategy element because its composition is usually provided (Chao \& Derdenger, 2013). Bundling provides discussion facilities and seminars to community members. Practically, the community should fulfill a certain percentage of its members to access the local newspaper's facilities. The community needs a place of communal interaction for this facility to fulfill their needs freely. Newspaper bundling supports community interaction directly other than through online.

$\mathrm{QR}$ is a matrix code or barcode with two dimensions created by a Japanese Company, Denzo-Wave, in 1994. It is a technology that rapidly transmits information with quick responses. Many media companies in Europe had used QR Code technology. In Indonesia, Kompas Daily was the first media that used the code. Concerning newspapers, this code functions to connect between offline and online news. While printed news media is static and less interactive, online news is rich in content, colorful, manifold, and engaging.

Code application to the local paper fulfills the community's hopes of manifold and colorful news content. The public wants more news about their communities, and a limitation of pages often cannot meet this expectation. Therefore, the code solves this problem by putting it on each printed paper to access better and exciting news. The news is presentable in infographics. This service meets people's expectations and increases the reason for subscribing to this paper.

A shared workspace is a social group of people working individually, although they may share certain values and work together. It offers a free solution to isolation that may be experienced. A shared workspace must be paid for, although there are undoubtedly free places.

According to the Head of Research and Savills Indonesia Consultancy, Anton Sitorus, a shared workspace, is a solution to the needs of work locations and offices. The introduction of the workspace was 
very aggressive and continues to expand in Indonesia. It was a sign that more people are needed to work in certain spaces (Ulfah, 2018) freely. Therefore, this new idea could enable the local paper to develop a close relationship with its communities. The workspace does not need a luxury place, but only a working desk and a chair, free Wi-Fi, as well as using air conditioning. The local paper may create a suitable system and provide the workspace to its communities. In this space, communities could access the old and new editions of the local paper. Furthermore, the communities could learn how to use data from the paper to support their work.

To engage with its communities, the local paper may provide regular serial news. In this way, the members could read about their community in the local newspaper. The local newspaper needs to fulfill its communities' hope of consuming regular news about their activities. This may increase the communities' engagement with the paper.

Community Award is an annual program that is conducted by the local paper. The program aims to develop a close relationship between the local paper and the community in Semarang. Many communities were involved in this program, and some of them emerged winners of the award. This program was effective enough to attract many local communities. During the award season, each community was published (Sunarto, Nugroho, et al., 2018).

This local paper recently created an award for village leaders (Kepala Desa). All the villages in Semarang City participate in this competition for the top position in the city. Every day, each village leader was to introduce the programs and innovations of their respective region to Semarang people. It was an effort of the local paper to develop community engagement in the region. This program was initiated by cooperation with the local government. All village leaders were enthusiastic about this competition, as evidenced by their publication in the local paper. The local people gave positive comments regarding their village leaders. 
Business departments seem to be in line with Pearce II \& Robinson, Jr. (2016), that the document with strategic ways would empower organization competencies to overcome problems. Programs that are relevant to community needs are created by explicitly mentioning the community. As a result, community engagement is realized at the end of the business processes.

\section{CONCLUSION AND SUGGESTION}

\section{Conclusion}

Internal regulation, as a manifestation of internal policy related to editorial matters, did not explicitly mention the existence of local communities. However, community existence was mentioned in internal business regulation. Community Award was a regular program held yearly to develop a close relationship between the local newspaper and its communities.

The local newspaper needs to improve its internal policy while processing input from its top leader. As an input, the actualization of a new idea needs to be followed by tangible action after well-documented. The actualization should be in a formal document as an internal regulation to guide all employees in all departments in achieving their strategic goals.

Socially, focusing on communities in internal media regulation is excellent guidance to other local or national media. This is because the rules are used as the organization's strategic planning for the media to determine short, middle, and long term goals. It unites all the units to collaborate and focus on their responsibilities to achieve organizational goals.

\section{Suggestion}

In the future, communities are to play a significant role in influencing its members' cognitive and affective behavior. Therefore, the local media 
should direct more attention to the local communities to realize a better future economically. In this regard, further studies should focus on how local communities consume media content that serves them.

\section{REFERENCES}

Albarran, A. B. (2006). Historical Trends and Patterns in Media Management Research. In A. B. Albarran, S. M. Chan-Olmsted, \& M. O. Wirth (Eds.), Handbook of Media Management and Economics (pp. 3-22). New Jersey, United States: Lawrence Erlbaum Associates Publishers.

Aristotle University of Thessaloniki. (2020). Internal Regulation. Retrieved March 4, 2020, from auth.gr website: https://www.auth. gr/en/regulation\#: :text=The $\% 20$ Internal $\% 20$ Regulation $\% 20$ defines $\% 20$ the,fully $\% 20$ conform $\% 20$ to $\% 20$ relevant $\% 20$ laws.

Blind, K., Petersen, S. S., \& Riillo, C. A. F. (2017). The Impact of Standards and Regulation on Innovation in Uncertain Markets. Research Policy, 46(1), 249-264. https://doi.org/10.1016/j.respol.2016.11.003

Chao, Y., \& Derdenger, T. (2013). Mixed bundling in Two-sided Markets in the Presence of Installed Base Effects. Management Science, 59(8), 1904-1926. https://doi.org/https://doi.org/10.1287/ mnsc. 1120.1688

Daft, R. L. (2012). New Era Of Management, Boston, Massachusetts, United States: Cengage Learning

Firmstone, J. (2016). Mapping Changes in Local News. Journalism Practice, 10(7), 928-938. https://doi.org/17512786.2016.1165136

Firmstone, J., \& Coleman, S. (2014). The Changing Role of the Local News Media in Enabling Citizens to Engage in Local Democracies. Journalism Practice, 8(5), 596-606. https://doi.org/10.1080/175127 86.2014 .895516

Hendrickson, C. (2019). Local Journalism in Crisis: Why America Must Revive Its Local Newsrooms. Retrieved from https://www.brookings.edu/ research/local-journalism-in-crisis-why-america-must-revive-itslocal-newsrooms/ 
Hess, K. (2012). Breaking Boundaries: Recasting the "Local" Newspaper as "Geo-social" News in a Digital Landscape. Digital Journalism, 1(1), 48-63. https://doi.org/10.1080/21670811.2012.714933

Hess, K., \& Waller, L. (2013). Geo-Social Journalism: Reorienting the Study of Small Commercial Newspapers in a Digital Environment. Journalism Practice, 8(2), 121-136. https://doi.org/10.1080/175127 86.2013 .859825

Iqbal, M. (2019). Koran Malaysia Berumur 80 Tabun Ini Tutup, 800 Karyawan di PHK. Retrieved October 25, 2019, from cnbcindonesia.com website https: / / www.cnbcindonesia.com/news/201910092006064-105732/koran-malaysia-berumur-80-tahun-ini-tutup-800karyawan-phk

Koop, C., \& Lodge, M. (2017). What is Regulation? An Interdisciplinary Concept Analysis. Regulation and Governance, 11(1), 95-108. https:// doi.org/10.1111/rego.12094

Maulsby, W. S. (1925). Getting the News. San Diego, California, United States: Harcourt, Brace \& Howe.

McQuail, D. (2005). McQuail's Mass Communication Theory (5th Ed). Thousand Oaks, California, United States: SAGE Publications.

Merdeka, S. (2019). suaramerdeka.com/ regional. www.suaramerdeka.com

Merriam-Webster. (2018). Community. Retrieved October 25, 2019, from merriam-webster.com website: https://www.merriam-webster. com/dictionary/community

Mulia, P. (2020). Menolak Mati. Retrieved March 4, 2020, from koran.tempo. co website: https://koran.tempo.co/read/fotografi/453676/ menolak-mati

Napoli, P. M., Stonbely, S., McCollough, K., \& Renninger, B. (2016). Local Journalism and the Information Needs of Local Communities: Toward a Scalable Assessment Approach. Journalism Practice, 11(4), 373-395. https:// doi.org/10.1080/17512786.2016.1146625

Pearce II, J. A., \& Robinson, Jr., R. B. (2016). Manajemen Strategis: Formulasi, Implementasi, dan Pengendalian (Strategic Management: Formulation, Implementation, and Control). Jakarta: Salemba Humanika.

Radford, G. P. (2005). On The Philosophy of Communication. Belmon, California, Unites States: Thomson Wadsworth. 
Rizky, P. A. (2018). Menakar Umur Media Cetak Indonesia. Retrieved October 25, 2019, from alinea.id website: https://www.alinea.id/media/ menakar-umur-media-cetak-indonesia-b1Uuz98E

Romero, M., \& Lambropoulos, N. (2011). Internal and External Regulation to Support Knowledge Construction and Convergence in Computer Supported Collaborative Learning (CSCL). Electronic Journal of Research in Education Psychology, 9(1), 309-330. https:// doi.org/10.25115/ejrep.v9i23.1439

Sadiq, S., \& Governatori, G. (2015). Managing Regulatory Compliance in Business Processes. In M. Rosemann \& J. vom Brocke, Handbook on Business Process Management 2: Strategic Alignment, Governance, People, and Culture (2nd Ed.). Berlin, Germany: Springer. https:/ / doi.org/10.1007/978-3-642-45103-4_11

Sadono, S. Y. B., \& Thobary, H. R. (n.d.). Buku Pintar Wartawan. Semarang: Suara Merdeka.

Serikat Perusahaan Pers. (2018). Pertumbuhan Media Cetak Per Wilayah Se-Indonesia Tabun 2014-2018 (I. A. W. (ed.)). Jakarta: Serikat Perusahaan Pers (SPS) Pusat.

Shaker, L. (2014). Dead Newspapers and Citizens' Civic Engagement. Political Communication. Political Communication, 31(1), 131-148. https://doi.org/10.1080/10584609.2012.762817

Strube, M. (2010). Development of Transnational Media Management Research from 1974-2009: a Propositional Inventory. International Journal on Media Management, 12(3), 115-140. https://doi.org/10.1 080/14241277.2010.531335

Sudarto, Bisri, A. Z., \& Heryanto, B. P. (2011). Lebih Padat. Lebih Segar. Lebih Cerdas. Standar Penyajian Halaman dan Pedoman Ragam Penulisan Harian Suara Merdeka Format 8 Kolom. Semarang: Suara Merdeka.

Sularto, S. (2012). Syukur Tiada Akbir: Jejak Langkah Jakob Oetama. Jakarta: Kompas.

Sunarto, Nugroho, A., Indrayana, H., \& Toto, A. (2016). Innovation Policy of A Regional Paper in Semarang, Indonesia. Proceedings of the 2016 International Conference on Public Management (ICPM 2016), 37-39. https://doi.org/10.2991/icpm-16.2016.11

Sunarto, Nugroho, A., Purbaningrum, D., Lestari, A. P., Indrayani, H., \& Tunggal, I. D. A. (2018). Local Media and Local Community in 
Semarang. Proceedings of the 3rd International Conference on Indonesian Social \& Political Enquiries (ICISPE 2018). https://www.atlantispress.com/proceedings/icispe-18/125922568

Sunarto, Purbaningrum, D., Nugroho, A., Indrayani, H., \& Lestari, A. P. (2018). Inequality Publication of Local Communities in Local Paper. The 3rd International Conference on Energy, Environmental, and Information System (ICENIS 2018), 73. https://doi.org/10.1051/ e3sconf/20187313012

Sylvie, G., \& Weiss, A. S. (2012). Putting the Management into Innovation \& Media Management Studies: a Meta-Analysis. International Journal on Media Management, 14(3), 183-206. https://doi.org/10.1080/14 241277.2011.633584

Tempo.co. (2013). Daftar Media Cetak Amerika yang Gulung Tikar. Retrieved October 25, 2019, from dunia.tempo.co website: https://dunia. tempo.co/read/502699/daftar-media-cetak-amerika-yanggulung-tikar

Ulfah, F. U. (2018). Coworking Space Jadi Penyelamat Bisnis Perkantoran. Retrieved October 25, 2019, from ekonomi.bisnis.com website: https://ekonomi.bisnis.com/read/20181220/47/871806/ coworking-space-jadi-penyelamat-bisnis-perkantoran

Utomo, W. P. (2015). Media Cetak yang Berhenti Terbit Tabun 2015. Retrieved October 25, 2019, from remotivi.or.id website: https://www. remotivi.or.id/kabar/247/media-cetak-yang-berhenti-terbittahun-2015-

Wadbring, I., \& Bergström, A. (2015). A Print Crisis or a Local Crisis? Local News Use Over Three Decades. Journal of Journalism Studies, 18(2), 175-190. https://doi.org/10.1080/1461670X.2015.1042988 
Al-Balagh: Jurnal Dakwah dan Komunikasi,

Vol. 5, No. 1, January - June 2020, pp. 141 - 164, DOI: https:/ / doi.org/10.22515/al-balagh.v5i1.2169 ISSN: 2527-5704 (P) ISSN: 2527-5682 (E) 